\title{
Realisme Hukum: Peradilan Adat dalam Perspektif Keadilan Sosial
}

\section{Dominikus Rato* \\ University of Jember, Jember, Indonesia}

\begin{abstract}
Aspects of positivism with its normative approach are often taught in various law schools as a single perspective. The study of law can be based on legal realism. Nevertheless, there is still a debate about legal realism's working pattern and contribution to juridical science. This study that introduced legal realism worked with socio-legal method based on the literature review. It aimed to elaborate on the concept of legal-realism as an epistemology of the socio-legal school, which leads to the conception of customary law and legal anthropology. With a naturalistic approach and supported by theories of customary law and legal anthropology. This study showed that legal realism as a school in philosophy and juridical studies based on empirical studies need to be developed. It refered to legal-realism conceptualized in Scandinavia and America that was suitable to Indonesia's legal context, especially customary law as the law that lives in society. Therefore, the law that lives in society is strengthened through verdict and law enforcement officers as symbols of the state. It suggested that legal realism is also taught in law schools at universities, so that legal academics have diverse points of view, both in the legal discipline and as a research method.
\end{abstract}

KEYWORDS: Customary Law, Socio-Legal, Social Justice, Legal Realism License. All writings published in this journal are personal views of the authors and do not represent the views of this journal and the author's affiliated institutions.

\section{HOW TO CITE:}

Rato, Dominikus, "Realisme Hukum: Peradilan Adat dalam Perspektif Keadilan Sosial" (2021) 1:2 Jurnal Kajian Pembaruan Hukum 285-308. DOI: $<$ https://doi.org/10.19184/jkph.v1i2.24998>.

Submitted: 27/06/2021 Reviewed: 29/06/2021 Revised: 29/07/2021 Accepted:31/07/2021

\footnotetext{
* Corresponding authors' e-mail: dominikusrato@gmail.com
} 


\section{PENDAHULUAN}

Beberapa tahun terakhir ini telah menimbulkan semacam kerasehan di kalangan para ilmuwan hukum karena perkembangan keilmuan hukum mengalami stagnasi. ${ }^{1}$ Hukum mainstream yaitu paradigma positivisme yang kaku, statis dan kurang membukan diri bagi paradigma di luar dirinya. Perkembangan ilmu hukum di Indonesia mati suri dan lemas, sehingga berbagai upaya dilakukan. Lima tahun terakhir, perkembangan ilmu hukum selain paradigma meanstream itu terus merangkak maju. Paradigma baru sebagai pemberi roh terhadap perkembangan itu adalah legal-realisme yang dikembangkan dan malahirkan pendekatan baru dalam ilmu hukum yaitu socio-legal approach. Socio-legal approach sebagai instrumen legalrealisme ini menekankan pada fakta nyata, bukan pada logika saja.

Sila kelima Pancasila sebagai landasan falsafah bangsa Indonesia menyatakan bahwa "Keadilan Sosial Bagi Seluruh Rakyat Indonesia." Sila ini, jika dilihat dari perspektif filsafat ilmu, maka Sila Kelima ini merupakan axiology dari Pancasila sebagai Landasan Filsosofis Ilmiah Ilmu Hukum. Pengertian demikian, hendak menyatakan bahwa pembangunan hukum, pembentukan hukum, pelaksanaan hukum, penegakkan hukum di Indonesia mengarah pada "Keadilan Sosial Bagi Seluruh Rakyat Indonesia" artinya dalam filsafat hukum, Indonesia menganut paham Social Justice, ${ }^{2}$ bukan Social Welfare. Jika orientasinya adalah social justice, maka bukan

1 Arief Budiono \& Wafda Vivid Izziyana, “Theistic Legal Realism (Suatu Pilihan Radikal bagi Pengembangan Hukum)" (2018) Huk Transendental Pengemb dan Penegakan Huk di Indones 367-383 at 367.

2 A Alfitri, "Ideologi Welfare State Dalam Dasar Negara Indonesia: Analisis Putusan Mahkamah Konstitusi Terkait Sistem Jaminan Sosial Nasional" (2012) 9:3 J Konstitusi 449-472 at 450; Ahmad Fadlil Sumadi, "Hukum dan Keadilan Sosial dalam Perspektif Hukum Ketatanegaraan" (2016) 12:4 J Konstitusi 849_ 871 at 850 . 
hanya kebutuhan lahiriah (ekonomi $=$ kesejahteraan lahiriah $=$ social welfare) belaka melainkan baik fisik (ekonomi), maupun kebutuhan batin yaitu keadilan (justice). Social justice merupakan roh dari pembangunan hukum Indonesia yang berbasis Pancasila. Oleh karena Pancasila merupakan roh asli Bangsa Indonesia dimana hukum adat yang menjadi hukum asli bangsa Indonesia, maka social justice adalah anak kandung yang lahir dari rahim hukum adat.

Hukum adat dalam cara kerjanya bersifat holistic artinya tidak ada pemisahan antara hukum materiel dan hukum formal, hukum perdata dan hukum pidana, hukum tata tantra (negara) dan hukum rakyat. Kemanunggalan yang demikian, dapat terlihat dalam pepatah, negara mawa tata, desa maw acara (baca: negoro mowo toto, deso mowo coro). ${ }^{3}$ Pepatah ini hendak menyatakan bahwa 'negara mempunyai hukum, desa mempunyai tata cara.' Desa dan negara, hukum dan tata cara adalah tunggal dan manunggal (holistic). Ekspresi dari hukum yang demikian, dikaji oleh para ahli hukum seperti Van Vollenhoven, ter Haar, Soepomo, Hazairin, dan beberapa ahli hukum adat. Para ahli hukum adat ini, pada awal Pendidikan mereka, termasuk Ter Haar berdasarkan pada paradigma legalrealisme yang dipandegani oleh Karl Llewelyn, Jerome Frank, Oliver Wendel Holmes. Aliran ini merupakan perkembangan dari Historisme yang dibangun oleh Von Savigny.

Pandangan ini sebagai bentuk penolakan terhadap paradigma naturalisme yang idealis-filosofis (abstrak) dan paradigma positivisme yang logis-legalis (abstrak). Realisme hukum mengandalkan pemikiran yang nyata (empiric) dan dapat dipertanggungjawabkan secara ilmiah. Agar lebih jelas, beberapa

3 Udiyo Basuki, "Desa Mawa Cara Negara Mawa Tata: Dinamika Pengaturan Desa Dalam Sistem Ketatanegaraan Indonesia" (2017) 5:2 Al-Mazahib 321-344 at 333 . 
contoh peradilan adat yang dikuatkan oleh peradilan negara. Misalnya kasus peradilan adat di Sulawesi Tengah yang dikuatkan oleh Putusan Mahkamah Agung. Dari penjelasan singkat diatas, muncul dua isu hukum dalam penelitian hukum ini. Pertama, bagaimana legal-realism itu bekerja? Kedua, apa kontribusi legal realism pada ilmu hukum? Untuk menjawab pertanyaan itu, teori-teori hukum adat dan antropologi hukum digunakan. Penggunaan teori hukum adat, khususnya peradilan adat, sebab para hakim adat dalam peradilan adat adalah para fungsionaris hukum yang tahu dan memahami hukum, para fungsionaris ini pula sebagai pelaksana dan penegak hukum. Para fungsionaris hukum bukan hanya hakim, tetapi mereka pulalah yang mengevaluasi jika ada norma hukum (adat) yang sekiranya telah ketinggalan zaman, ketinggalan dengan kebutuhan hukum (keadilan) yang nyata dari masyarakatnya. Para fungsionaris hukum juga penerus sekaligus pengevaluasi norma hukum, dekat dan merasakan perasaan hukum dan keadilan masayarakatnya.

Penelitian ini menggunakan teori antropologi hukum, oleh karena penelitian hukum yang demikian ini, yaitu legal-realisme ini sekalipun diciptakan oleh para juris; tetapi perkembangan selanjutnya dilakukan oleh para antropolog. Para antropolog hukum melakukan penelitian untuk mencari, menemukan dan membuktikan kebenaran pola pikir para realisme hukum ini dalam kenyataannya sebagaimana diteorikan oleh aliran ini. Hasil kajian dan penelitian para antropolog hukum inilah yang menemukan dan membuktikan kebenarannya, sehingga mereka pulalah yang mengembangkannya. Oleh karena itu, ada kesalahpahaman bahwa legal-realisme ini bukanlah ilmu hukum, tetapi ilmu sosial, yaitu antropologi. Pandangan yang demikian ini telah mengkerdilkan dan membatasi perkembangan ilmu hukum. 


\section{METODE}

Jenis penelitian hukum ini adalah socio-legal; dengan menggunakan metode kajian pustaka. Sasarannya adalah legal-realism paradigm dan socio-legal sebagai metodenya. Metode kajian pustaka dan dianalisis secara deskriptif karena sedikit sekali sarjana hukum yang melakukan kajian ini kecuali para legal-antropolog. Pendekatan ini didukung dengan beberapa wawancara kecil/sederhana dengan para hakim, lawyer, dan para pihak yang sedang terlibat dalam sebuah kasus. Sebagaimana Skandinavian legal-realism lakukan terhadap kasus-kasus penting, dimana barang bukti yang diambil sebagai bukti nyata; bahwa faktor-faktor keterlibatan langsung dalam pengambilan keputusan yuridis sebagaimana ditekankan oleh aliran ini, terpenuhi.

\section{REALISME HUKUM: SEBUAH KAJIAN TEORI}

Awal mula realisme hukum adalah sebagai sebuah legal-movement (gerakan hukum); berasal dari ketidakpercayaan (unbelieve) kepada hukum mainstream saat itu (hukum alam) yang menekankan elemen etika dan moral.4 Oleh karena itu, aliran legal-realism (realisme hukum) mendapat counterpart berbentuk gerakan yang menekankan unsur kenyataan (empiricisme); seperti begrijftjurisprudenz oleh Rudolf von Ihering, ${ }^{5}$ Interresentjurisprudencz oleh Otto von Gierke di Jerman, ${ }^{6}$ dan aliran Historisme (Aliran Hukum Sejarah dan Kebudayaan) dari

4 Rizal Mustansyir, “Landasan Filosofis Mazhab Hukum Progresif: Tinjauan Filsafat Ilmu" (2016) 18:1 J Filsafat 15-25 at 18.

5 Rudolf von Jhering, Law in Daily Life. Diterjemahkan oleh Henry Goudy (Oxford: Clarendon Press, 1904) at 12.

6 Otto von Gierke, The Social Role of Private Law. Diterjemahkan oleh Ewan McGaughey, In King's College London Law School Research Paper. Centre for Business Researh. Cambridge: University of Cambridge; California: California University Press; Berkeley: Berkeley Centre on C (2017) at 65. 
Von Savigny ${ }^{7}$ dari Jerman, dan Freierechtslehre dari Eugen Ehrlich dan Kantorowicz, Free Law Movement oleh Emile Durkheim, Sociology of Law oleh Max Webber dan Karl Marx, dan Egological oleh Carlos Cossio di Argentinia. ${ }^{8}$

Begrijftjurisprudenz adalah sebuah aliran yang melihat bahwa undang-undang yang penuh dengan kelemahannya itu dapat diisi dengan logika-logika hukum; melalui penemuan hukum oleh hakim. Hakim dapat menggunakan syllogism sebagaimana diajarkan oleh Aristoteteles. Undang-undang sebagai premis mayor dan fakta-fakta hukum dari suatu kasus hukum menjadi premis minor, kemudian diambil kesimpulan atau syllogism. Undang-undang dapat memperluas cakupannya melalui metode interpretasi-interpretasi untuk menemberikan kepastian hukum; yang disebut normlogisch (logika hukum). Aliran ini kurang memperhatikan keadilan; yang terpenting adalah kepastian hukum untuk memberikan kepastian hak seseorang.

Tokohnya adalah Rudolf von Ihering yang melihat kelemahan hukum di Jerman saat itu; dimana undang-undang yang dibentuk saling bertentangan satu sama lain, oleh karena undang-undang yang dibentuk itu bukan merupakan sebuah system. Oleh sebab itu, undang-undang sebagai hukum haruslah dibangun secara sistemtis. Sebagai sebuah system, maka undang-undang itu saling terkait secara fungsional satu dengan lainnya. Dengan demikian, undang-undang merupakan system yang tertutup.

7 Friedrich Carl von Savigny, System of the Modern Roman Law. Diterjemahkan oleh William Holloway (Madras: J. Hingginbotham Publisher, 1867) at 42.

8 Damang Averroes Al-Khawarizmi, "Relisme Skandinavia", (2011), online: Negara Huk<https://www.negarahukum.com/relisme-skandinavia.html>. 
Ada 2 (dua) aliran legal-realism ini; yaitu legal-realism Skandinavia dan legal-realisme Amerika. ${ }^{9}$ Legal-realism Skandinavia merupakan bentuk resistensi atau penolakan terhadap budaya hukum Eropa Continental. Pandangan ini bermula dari positivisme hukum eropa continental yang lahir dari rahim positivisme yang mengunggulkan kajian rasionalisme empiric; sebagaimana dalam ilmu pengetahuan alam (sains). Pandangan ini berawal dari pandangan bahwa ilmu-ilmu non sains bukanlah ilmu pengetahuan; sehingga, diragukan keilmiahannya. Hal ini mendorong para ahli hukum mencari cara untuk membuktikan bahwa hukum juga merupakan ilmu pengetahuan (science). Hal ini perlu dicari dan ditemukan ilmu yang mampu menghubungkan antara bahasa dan logika. ${ }^{10}$ Bahasa sebagai bahan dasar dalam hukum dan logika sebagai syarat dasar dari sebuah ilmu pengetahuan, harus dipertemukan dalam satu paradigma.

Realisme hukum Skandinavia lebih empirical daripada Realisme Hukum Amerika. Para penganut legal-realism Skandinavia seperti Axel Hegerstrom, ${ }^{11}$ Olivecrona, Lundstet, dan Ross secara tegas menolak pandangan hukum yang metafisik, dan lebih mengedepankan dan mengutamakan nilai-nilai, asas dan norma hukum yang mampu diverifikasi secara ilmiah atas fenomena hukum yang empiric (nyata, factual). Para penganut aliran ini, pada sisi lainnya juga menolak dan mengkritik ajaran Positivisme Hukum dari John Austin dan Hans Kelsen; oleh karena, John Austin

9 Vidya Prahassacitta, "Pandangan Realisme Dari Hukum Jerome Frank", (2018), online: Binus Univ Fac Humanit <https://businesslaw.binus.ac.id/2018/11/09/pandangan-realisme-hukum-dari-jerome-frank/>.

10 Keith J Bybee, "Legal Realism, Common Courtesy, and Hypocrisy" (2005) 1:1 Law, Cult Humanit 75-102 at 75-77.

${ }^{11}$ Enrico Pattaro, "I Will Tell You about Axel Hägerström: His Ontology and Theory of Judgment" (2010) 23:1 Ratio Juris 123-156 at 125. 
melepaskan begitu saja tanpa penjelasan yang lengkap dan tuntas atas berbagai karakteristik yang hakiki dari hukum. ${ }^{12}$

Pandangan legal-realism Skandinavia lebih mendekati hukum adat. Legal-realism Skandinavia memandang hukum berfungsi dalam masyarakat bukan karena rasa takut kepada penguasa atau karena atas perintah penguasa serta takut pada sanksi. Masyarakat taat pada hukum karena mereka meyakini bahwa hukum itu baik dan benar serta layak untuk ditaati, dilestarikan dan dikembangkan. Keberlakuan hukum adat yang benar dan sempurna sebab dalam hukum adat itu mempunyai keberlakuan baik secara filosofis, normative, dan sociologis. Perbedaan pokok legal-realism Skandinavia dengan legal-realism Amerika adalah bahwa legal-realism Skandinavia lebih menekankan pada putusan dan pertimbangan hukum hakim, sedangkan legal-realism Amerika lebih menitikberatkan pada hukum yang berlaku sebagai kenyataan yang hidup dalam masyarakat. ${ }^{13}$ Persamaan keduanya, sama-sama menggunakan metode empiric yaitu socio-legal approach sebagai epistemologinya. Kedua aliran ini, sekalipun berbeda objek kajian, namun jika disatukan, akan menghasilkan kajian hukum yang sangat bermanfaat untuk pengembangan ilmu hukum.

Di Amerika Serikat muncul awal abad 20 atau akhir abad 19, bersamaan dengan Yurisprudensi Amerika selama tahun 1920-1930. Ilmuwan Amerika seperti Karl Llewellyn, ${ }^{14}$ menyatakan bahwa hukum adalah instrument yang digunakan oleh negara dan masyarakat (subjek hukum) untuk mencapai tujuan-tujuan sosial, dan hendaknya konsepsi-konsepsi hukum itu menyinggung atau

12 Al-Khawarizmi, supra note 8.

13 Ibid at 10.

14 Karl Llewellyn, "Some Realism about Realism: Responding to Dean Pound" (1931) 44:8 Harv Law Rev 1222-1264 at 1222-1223. 
melibatkan hukum yang dinamis serta yang dilahirkan oleh masyarakat dan direalisasikan melalui putusan hakim. Sebagaimana dikemukakan oleh Keith Bybee; ${ }^{15}$ bahwa legal-realism selalu dan senantiasa mengekspos peran yang dimainkan oleh politik dalam pengambilan keputusan yuridis oleh hakim, dan ketika melakukan hal itu, yaitu kritik dan mempertanyakan upaya klasik dan konvensional untuk mempertahankan kekuasaan kehakiman pada landasan yang baku dan netral (tidak memihak). Dengan demikian, para ahli hukum kontemporer menemukan cara berpikir baru untuk keluar dari paradigma hukum mainstream, legal-positivism. ${ }^{16}$

Pandangan ini sekaligus merupakan kritik terhadap pandangan legal-positivism dari Hart. ${ }^{17}$ Brian menyatakan bawa hukum tidak selalu memberikan kepastian hukum dan ada sedikit kelonggaran yang dibenarkan untuk pembuatan kebijakan yudisial. Hal ini sejalan dengan pandangan yang dikemukakan oleh Leiter bahwa hukum sebagaimana seharusnya dengan hukum yang senyatanya terjadi dalam peradilan sering pula tidak sejalan. Ada semacam petimbangan khusus berkaitan dengan politik hukum kedepan yang berbeda dengan apa yang diharapkan oleh masyarakat. Hukum senyatanya yang terjadi selama dan dalam proses peradilan itulah yang benar-benar hukum. Hukum yang demikian, sering disebut hukum empiric, namun yang benar adalah hukum yang real sehingga disebut realisme hukum.

15 Bybee, supra note 10.

16 William Twining, Karl Llewellyn and the Realist Movement (Law in context) (London: Weidenfeld \& Nicolson Ltd, 1973) at 112.

17 Brian Leiter, "American Legal Realism" in A Companion to Philos Law Leg Theory (Oxford, UK: Wiley-Blackwell, 2010) at 249; Martin P Golding \& William A Edmundson, The Blackwell Guide to the Philosophy of Law and Legal Theory (United States: Wiley-Blackwell, 2004) at 65. 
Emprikisme yang disebutkan banyak orang berkenaan dengan metode empiric yang sering digunakan dalam kajian ilmu alam, ${ }^{18}$ natural secience. Hukum yang benar adalah kenyataan selama dan dalam proses peradilan itulah yang menjadi objek telaah kajian hukum legal-realism Skandinavia. ${ }^{19}$ Penggunaan istilah hukum empiric, oleh karena kebenaran yang dibangun adalah empiric dari dan dalam proses peradilan, bukan saja proses peradilan negara yang formal; tetapi, juga peradilan adat dalam masyarakat. ${ }^{20}$ American legal realism adalah sebuah aliran dalam filsafat hukum yang lahir pada awal abad 20;21 yaitu kurang lebih pada tahun 1920-1930-an di Amerika, pada masa Pemerintahan Presiden F.D Rooselvelt, terutama di antara para hakim federal dan para lawyer. American legal realism atau realisme hukum Amerika ini merupakan sebuah Gerakan Hukum Empirik yang menolak pandangan hukum doctrinal-normatif yang hanya mengandalkan logika undang-undang semata. ${ }^{22}$ Legal realism ini menyatakan bahwa hukum dalam daya kerjanya, terutama di pengadilan memerlukan bukti dan pembuktian yang secara empiric dapat dipertanggungjawabkan secara ilmiah.

Pandangan ini kemudian melahirkan sebuah pendekatan yang saat ini dikenal dengan socio-legal approach. Orientasi paham atau paradigma American legal-realism ini adalah social justice (keadilan social), bukan hanya social-welfare. Putusan hakim menjadi sangat

18 Budiono \& Izziyana, supra note 1.

19 Nadir et al, "Philosophical Validity, Theoretical, Normative and Empirical Paradigm of General Principles of Good Governance (Aupb) As a Review of Presidential Impeachment" (2017) 4:1 Brawijaya Law J 95-116 at 101.

20 FC Susila Adiyanta, "Hukum dan Studi Penelitian Empiris: Penggunaan Metode Survey sebagai Instrumen Penelitian Hukum Empiris" (2019) 2:4 Adm Law Gov J 697-709 at 699.

21 Morton J Horwitz, “The History of the Public/Private Distinction” (1982) 130:6 Univ PA Law Rev 1423-1428 at 1424-1425.

22 Sumadi, supra note 2. 
penting, karena setiap kasus atau fakta sosial (social fact) atau gejala sosial (social phenomenon) yang menjadi latar belakang sebuah kasus, bersifat unik. Hakim wajib mencari dan menemukan faktor-faktor yang demikian itu, untuk menemukan keadilan, keadilan sosial. Hakim tidak hanya menemukan hukum, tetapi hakim juga dapat membuat hukum, the law by judiciary. ${ }^{23}$ Socio-legal approach adalah sebuah pendekatan, sebuah cara dan strategi untuk menemukan hukum; bukan sebuah aliran atau mazhab dalam ilmu hukum. Legal realism atau aliran hukum realisme itulah yang menjadi aliran atau mazhab hukumnya dan socio-legal itu adalah pendekatannya. Aliran hukum realisme ini merupakan kelanjutan dari aliran naturalistic ilmu yang mengutamakan metode ilmu alam yang empiric. Preposisi hukum bukanlah pernyataan semata melainkan harus dapat dibuktikan secara nyata (empiric).

Kaum Realis ini memandang bahwa hukum harus dikaji dan diteliti secara nyata dan bukan hanya filosofis-logis semata yang mencari makna hukum yang terpisah dan menjauh dari praktik dan cara kerjanya. Oleh karena itu, alat bukti di pengadilan harus dikuatkan dengan barang bukti yang dapat dipertanggungjawabkan secara ilmiah. Persoalan hukum bukanlah persoalan logika semata; melainkan logika yang didukung dengan alat bukti, dan alat bukti harus dan wajib didukung oleh barang bukti yang valid. Oleh karena itu, ilmu hukum adalah ilmu yang bebas nilai dan didukung dengan pembuktiannya yang juga haruslah objektif dan bebas nilai.

Kaum Realis menegaskan bahwa hukum tidak boleh terpisah dan dipisahkan antara norma dengan pelaksanaannya, juga tidak dapat dipisahkan dengan penegakkannya. Dengan demikian, realisme hukum ini menekankan hukum sebagaimana adanya, bukan hukum

23 Benyamin N Cardozo, Characteristic of Judicial Proccess (New Haven: Yale University Press, 1921) at 55. 
sebagaimana mestinya. Penemuan hukum dalam aspek-aspek yang ditemukan dalam pendapat hukum, pertimbangan hukum hakim, yurisprudensi atau preseden masa lalu, dan stare decisis, menekankan factor-faktor keterlibatan langsung dalam pengambilan keputusan yuridis. Tujuan akhir dari hukum yang demikian adalah the living law yang berorientasi pada social-justice.

\section{KONTRIBUSI REALISME HUKUM: DINAMIKA DAN REFLEKSI}

Ada sebuah kasus yang diadili oleh Peradilan Adat yang kemudian dikuatkan oleh Mahkamah Agung yaitu Putusan MA. No. 984 K/Pid/1996, tanggal 30 Januari 1996.24 Pada putusan itu, Majelis Hakim (Agung) menyatakan bahwa jika pelaku zinah telah dijatuhi sanksi adat, atau mendapat reaksi adat dari para pemangku adat, dimana hukum adat masih hidup dan dihormati serta hidup subur, maka tuntutan jaksa harus dinyatakan tidak dapat diterima, niet ontvankelijk verklaard. Jika putusan peradilan adat telah dilaksanakan oleh yang bersalah, kemudian diadili oleh peradilan negara, maka hal itu bertentangan dengan azas nebis in idem. ${ }^{25}$ Putusan serupa pernah dilaksanakan sebelumnya yaitu Putusan MA. No. 1644K/Pid/1988 tanggal 15 Mei 1991. ${ }^{26}$

24 Tim Yuridisid, "Perselingkuhan Suami-Istri Sanksi Adat Hapuskan Penuntutan Jaksa", (2020), online: Yuridis.id $<$ https://yuridis.id/perselingkuhan-suami-istri-sanksi-adat-hapuskanpenuntutan-jaksa/>.

25 Masril Masril \& Ade Kosasih, "Keberlakuan Asas Ne Bis in Idem Terhadap Putusan Pengadilan Adat Dalam Tata Hukum Indonesia" (2019) 4:1 Al Imarah J Pemerintah Dan Polit Islam 49-56 at 49-50.

26 Nyoman Serikat Putra Jaya, "Hukum (Sanksi) Pidana Adat Dalam Pembaharuan Hukum Pidana Nasional" (2016) 45:2 Masal Huk 123-130 at 124. 
Kasus diatas berawal dari seorang laki-laki, berstatus sebagai suami dari sebuah keluarga, berselingkuh dengan seorang wanita, berstatus sebagai isteri dari sebuah keluarga lain, (dari dua keluarga yang berbeda). Laki-laki ini berdomisili di Desa Parauna, Kecamatan Unaaha, Kodya Kendari, Sulawesi Tengah. Kasus ini diselesaikan oleh Peradilan Adat Tolake, Desa Parauna, Kecamatan Unaaha, Kodya Kendari, Sulawesi Tengah, berupa denda adat yang disebut prohala. Sanksi adat prohala ini berupa seekor kerbau dan satu piece kain kaci. Laki-laki yang berzinah ini mentaati denda adat dengan membayar prohala. Akan tetapi, kasus ini sekalipun telah membayar denda adat, oleh Penyidik Polri diteruskan ke Pengadilan Negeri Kendari. Hakim Pengadilan Negeri memutuskan bahwa si lelaki pelaku zinah itu dinyatakan bersalah dan meyakinkan telah melakukan perbuatan 'zinah' dengan cara 'memperkosa.' Lawyer si pelaku zinah mengajukan keberatan dengan alasan 'nebis in idem;' namun, ditolak oleh hakim. Kasus ini terus berlanjut hingga ke Pengadilan Tinggi Kendari; kemudian, Hakim Pengadilan Tinggi Kendari menguatkan Putusan Yudex Factie Pengadilan Negeri Kendari.

Lawyer dari si pelaku zinah itu meneruskannya ke tingkat kasasi di Mahkamah Agung. Hakim Mahkamah Agung menyatakan bahwa Ketika si pelaku telah membayar denda adat, prohala, berupa 1 (satu) ekor kerbau dan satu piece kain kaci, kemudian dibawa ke Pengadilan Negara, maka Jaksa wajib menolak dengan asalan nietig ontvankelijke verklaard. Alasan hakim adalah bahwa perkara yang telah diputuskan oleh Peradilan Adat dan putusan peradilan adat sudah tetap dan dilaksanakan, kemudian diadili oleh Peradilan Negara, bertentangan dengan asas nebis in idem. Dasar hukum pidana bukan hanya KUHP yang keberlakuannya sejak 1 Januari 1918, tetapi juga di luar KUHP. Pasca kemerdekaan juga peradilan adat diatur dalam UU Drt. No. 1 
tahun 1951 tentang Tindakan-Tindakan Sementara untuk Menyelenggarakan Kesatuan Susunan Kekuasaan dan Acara Pengadilan-Pengadilan Sipil, dalam Pasal 5 ayat (3) yang intinya menyatakan bahwa:

"Jika pidana adat yang tidak ada bandingannya/padanannya dalam KUHP, pidana adat yang ada bandingannyalpadanannya dalam KUHP, dan sanksi adat. Sanksi adat dapat dijadikan pidana pokok atau pidana utama oleh hakim dalam memeriksa dan mengadili perbuatan yang menurut hukum yang hidup (hukum adat) dianggap sebagai tindak pidana yang tidak ada bandingannyalpadanannya dalam KUHP."

Pada saat ini dasar hukumnya ada dalam Pasal 18B ayat (2) UUD NRI Tahun 1945. Pasal ini menyatakan bahwa:

"Negara mengakui dan menghormati kesatuan-kesatuan masyarakat hukum adat beserta hak-hak tradisionalnya sepanjang masih hidup dan sesuai dengan perkembangan masyarakat dan prinsip Negara Kesatuan Republik Indonesia". ${ }^{27}$

Selanjutnya, perlu diperhatikan Pasal 5 ayat (1) UU No. 48 Tahun 2009 tentang Kekuasaan kehakiman yang menyatakan bahwa:

"hakim wajib menggali, mengikuti, dan memahami nilai-nilai hukum dan rasa keadilan yang hidup dalam masyarakat. Putusan pengadilan selain harus memuat alasan dan dasar putusan, juga memuat pasal tertentu dari peraturan perundang-undangan bersangkutan atau sumber hukum tak tertulis yang dijadikan dasar untuk mengadili."

Jika diperhatikan bunyi Pasal 5 ayat (1) UU No. 48 Tahun 2009 tersebut diatas, pada Alinea pertama dikatakan “... rasa keadilan yang

Lilik Mulyadi, "Eksistensi Hukum Pidana Adat di Indonesia: Pengkajian Asas, Norma, Teori, Praktik dan Prosedurnya" (2013) 2:2 J Huk dan Peradil 225-246 at 229. 
hidup dalam masyarakat ..." itu menunjukkan bahwa peradilan di Indonesia menganut 'social justice' sebagaimana terdapat dalam Sila Ke-V Pancasila "Keadilan Sosial bagi Seluruh Rakyat Indonesia."

Bagi legal-realisme Skandinavia, yang penting adalah adanya: a) peristiwa hukum; b) perbuatan hukum yang didukung oleh barang bukti; c) barang bukti memperkuat alat bukti, dan d) alat bukti memperkuat keyakinan hakim, sehingga keputusan hakim menjadi benar dan adil. Apa yang menunjukkan suatu peritiwa itu adalah peristiwa hukum? Kriteria utama hukum menurut legal-realisme Skandinavia sebagaimana dikatakan oleh Axel Hegerstrom;"28 bahwa hukum harus dibebaskan dari mitologi, teologi dan metafisika (sebab ia menolak mitologi Yunani sebagai dasar kekuasaan Roma menguasai dunia), melainkan pada investigasi empiric, yang dianalisis secara konseptual, historis (nyata), dan psikologis.

Oleh karena itu, kriteria hukum adalah: a) realistis yaitu adanya aturan (bukan peraturan) yang ditaati oleh masyarakat, baik karena perintah untuk dilaksanakan maupun oleh karena larangan yang wajib dihindari, b) sehingga masyarakat merasa bahwa apa yang mereka taati itu adalah benar, karena memberi rasa aman, tenang, tenteram, membawa keuntungan, keselamatan, c) yang dibuktikan dengan bukti-bukti nyata/factual. Hakim memutuskan berdasarkan realitas yang demikian itu, sehingga jika ada putusan hakim yang ditolak oleh masyarakat, maka putusan yang demikian, patut dicurigai.

Oleh sebab itu, secara konseptual; kriteria hukum adalah realitas social. Realitas sosial yang demikian, sehingga aliran ini disebut aliran sosiologis (bukan sociology of law), dan psikologis (bukan pchilology of law). Jika sociology of law atau sosiologi hukum dikaji oleh

28 Pattaro, supra note 11. 
para sosiolog yang menjadikan hukum sebagai objek kajian, sehingga ilmu itu menjadi bagian dari ilmu sosiologi. Psikologi hukum dikaji oleh para psikolog yang menjadikan perilaku para penegak hukum sebagai objek kajian (behavior of law). Realisme hukum (legal-realisme) sebagai kebalikan dari ilmu-ilmu yang demikian, yaitu para yurist (ahli hukum) yang melakukan kajian dengan meminjam pendekatan ilmu-ilmu social itu sebagai instrument penelitiannya. Instrument ilmu sosial yang dipinjam, karena sifat realitas (objek) yang dikajinya, bukan sifat ilmunya. Ilmu hukumnya, tetaplah normative, tetapi pelanggaran atau ketaatan terhadap hukum adalah social dan psikologis. ${ }^{29}$ Jadi, hukum harus dilihat dari bekerjanya hukum dalam masyarakat, pada setiap anggota masyarakat, dengan pertanyaan: "mengapa mereka taat pada hukum (putusan hakim)?"

Dengan demikian, dapat dikatakan bahwa ada 2 (dua) kriteria hukum, yaitu: a) Legal-realism berwatak sosiologis, karena pendekatan yang dilakukan oleh Skandinavian legal-realism menekankan pada pentingnya hukum dalam konteks kebutuhan hukum yang nyata dari masyarakat, sehingga disebut hukum yang sosiologis (sociological-yurisprudence) atau social life sebagai konteks social dari hukum, dan (b) aspek putusan hakim sebagai objek kajian keilmuan secara teoritis. ${ }^{30}$ Oleh karenanya, penekanannya pada putusan hakim yang sosiologis yaitu putusan hakim yang diterima oleh masyarakat, karena selaras dan serasi dengan kebutuhan hukum yang nyata, maka metode penelitiannya disebut socio-legal approach. ${ }^{31}$ Jadi, socio-legal itu bukan aliran dalam ilmu hukum, melainkan metode kajian dari aliran legal-realism.

29 Leiter, supra note 17.

30 Ibid.

31 Sulistyowati \& Shidarta (eds) Irianto, Metode Penelitian Hukum: Konstelasi $\mathcal{E}$ Refleksi (Jakarta: Yayasan Obor Indonesia, 2011) at 77. 
Kasus lain lagi, yaitu Yurisprudensi Mahkamah Agung No. 1644K/Pid/1988 tanggal 15 Mei 1991. Mahkamah Agung dalam putusannya tersebut menyatakan bahwa terhadap terdakwa yang telah melakukan tindak pidana perzinahan yaitu hubungan kalamin di luar perkawinan, dijatuhi sanksi adat (reaksi adat) oleh fungsionaris adat (kepala adat), tidak dapat diajukan untuk kedua kalinya kepada badan peradilan negara (Pengadilan Negeri) dengan dakwaan yang sama melanggar delik adat dan dijatuhi hukuman penjara menurut ketentuan hukum pidana yang diatur dalam KUHP. Jika hal itu terjadi, maka perbuatan tersebut bertentangan dengan asas nebis in idem. Akan tetapi, menurut beberapa ahli hukum pidana menyatakan bahwa tindak pidana perzinahan yaitu hubungan kelamin di luar perkawinan (yang sah) dikategorikan sebagai delik pidana yang tidak ada kualifikasinya dalam KUHP. ${ }^{32}$ Hal ini dimaksudkan bahwa terhadap tindak pidana yang ada bandingannya dengan KUHP; maka, tentu harus dijatuhi sanksi sesuai ketentuan dalam KUHP.

Pada tahun 1999,33 terjadi sebuah peristiwa pembunuhan yang dilakukan oleh warga Lopak Aur, Kecamatan Pemayung, Kabupaten Batang Hari. Peristiwa itu bermula dari seorang warga adat bernama Jaini menebang pohon duren milik adat dan ditegur oleh kepala desa bernama Jangte. Jangte kepala desa Pulau Betung, menegur sdr. Jaini dan dijawab oleh Jaini bahwa sebagai anggota masyarakat adat Pulau Betung, ia juga berhak untuk menebang pohon itu. Jangte, sebagai

32 Amrie Hakim, "Keabsahan Penyelesaian Kasus Pidana Melalui Pengadilan Adat", (2012), online: HukumOnline.com $<$ https://www.hukumonline.com/klinik/detail/ulasan/lt503844b38e417/351kuhp-delik-aduan-atau-pidana-murni->.

33 Fuad M Yusuf, "Tindak Pidana Pembunuhan yang Diselesaikan Secara Adat yang Tidak Sesuai dengan Perundang-Undangan (KUHP dan KUHAP) (Studi Kasus Desa Ture dan Desa Lubuk Ruso Kecamatan Pemayung di Kabupaten Batang Hari)" (2009) 9:2 J Ilm Univ Batanghari Jambi 34-46 at 37. 
Kepala Desa Pulau Betung yang bertanggungjawab atas keamanan dan keselamatan harta benda dan nyawa warga desa menegur bahwa sekalipun Jaini ikut berhak, namun secara etika, ia wajib minta ijin terlebih dahulu kepada desa. Namun, teguran itu ditantang oleh Jaini, dan tantangan itu dijawab oleh masyarakat desa dengan cara menyerbu Jaini di Kantor Polisi Pemayung, sehingga Jaini mati terbunuh bersama anaknya bernama Haidir bin Jaini.

Oleh karena kematian Jaini dilakukan oleh karena penyerbuan massa, Polisi tidak mampu berbuat banyak, sehingga atas inisiatif Lembaga Adat Kabupaten Batang Hari dan Kecamatan Pemayung dan para tua-tua adat; yaitu Tuo Tenganai (Tungganai) kedua pihak yang masih ada hubungan kerabat itu dikumpulkan dan diajar berdamai secara kekelurgaan berdasarkan hukum adat. Putusan kepala adat dihargai oleh negara dan memang demikian seharusnya negara ini memperlakukan hukum yang telah berakar dan hidup dalam masyarakat. Berdasarkan keputusan pengadilan adat, para pelaku (Jangte dan anggota masyarakat sebagai pelaku) dikenai denda adat berupa: 1 ekor kerbau, beras dan lauk pauk (selemas semanis) untuk disemeblih dan dimakan Bersama demi perekatan adat (integrasi social). Selain itu, Jangte dan para pelaku lainnya dikenai denda uang sejumlah Rp. 14.000.000,- (empat belas juta) untuk keluarga korban. Putusan ini memperlihatkan bahwa negara dan masyarakat merupakan ketunggalan dan saling menguatkan satu sama lain dalam penegakkan hukum.

Kasus itu tidak pernah dilanjutkan hingga ke pengadilan negara, sebab seluruh anggota masyarakat menerima denda adat tersebut sebagaimana telah disepakati bersama. Keluarga pelaku maupun korban hingga saat ini tetap hidup damai, tidak ada lagi dendam yang tersimpan. Kasus peradilan adat seperti ini menjadi objek kajian dari American legal-realisme, karena nyata-nyata hidup dan 
berkembang dalam masyarakat. Kontribusi American legal-realism telah memberikan dukungan yang cukup besar bagi perkembangan ilmu hukum dengan pendekatan socio-legal menuju social justice menjadi penting untuk dilakukan. Social justice atau keadilan social bagi seluruh rakyat Indonesia sebagaimana dirumuskan dalam Sila ke-V Pancasila yang diperjuangkan oleh Bung Karno, adalah tepat. ${ }^{34}$ Menurut Soediman Kartohadiprodjo ${ }^{35}$ bahwa pembangunan hukum (revolusi pembangunan hukum) layaknya berdasarkan dan bersumberkan pada Pancasila, sebab selaras dengan jiwa kekeluargaan dan gotong royong sebagai jiwa Bangsa Indonesia. Sekalipun juga melakukan kritik bahwa keadilan sosial cenderung condong ke liberalisme barat. Kekeluargaan sebagai ekspresi dari kemanunggalan dari: jiwa, raga, rasa, dan rasio yang selaras, akan lebih cocok disebut kesejahteraan social (social welfare). ${ }^{36}$ Jadi, jika Indonesia telah memilih social justice; maka yang dimaksud dengan social justice adalah kemanunggalan antara kesejahteraan sosial (social welfare) dan kebahagiaan (lahir batin, happiness, well being), sehingga jika dikaitkan dengan Indonesia sebagai negara hukum, maka disebut negara hukum sejahtera. ${ }^{37}$ Dengan demikian, keadilan sosial menjadi ideal hukum yang tepat untuk konteks Indonesia, atau dengan kata lain 'sistem hukum Pancasila.'

34 Yunie Herawati, "Konsep Keadilan Sosial dalam Bingkai Sila Kelima Pancasila" (2014) 18:1 Paradigma 20-27 at 20.

35 Soediman Kartohadiprodjo, Pengantar Tata Hukum di Indonesia. Jilid I: Hukum Perdata (Jakarta: PT. Pembangunan dan Ghalia Indonesia, 1982) at 59.

36 Lismanto Lismanto \& Yos Johan Utama, “Membumikan Instrumen Hukum Administrasi Negara Sebagai Alat Mewujudkan Kesejahteraan Sosial dalam Perspektif Negara Demokrasi" (2020) 2:3 J Pembang Huk Indones 416-433 at 418.

37 Shidarta, "Membaca Ulang Pemaknaan Keadilan Sosial Dalam Gagasan Revolusi Hukum Soediman Kartohadiprodjo" (2015) 1:1 Verit Justitia 20-38 at 28-29. 
Social justice yang dianut dalam sistem peradilan di Indonesia digawangi dan dibentengi oleh 2 (dua) Lembaga Tertinggi Peradilan Indonesia yaitu Mahkamah Agung dan Mahkamah Konstitusi. Social justice sebagai semangat pembangunan hukum dalam politik hukum Indonesia dilandasi secara konstutisional dalam Sila Ke-V Pancasila. Dalam politik hukum Indonesia kearah sanalah pembangunan hukum itu tertuju. Pencapaian social justice (Keadilan Social Bagi Seluruh Rakyat Indonesia) perlu didasari oleh moral keadilan (moral of justice) yang bersumber dari nilai Pancasila tersebut. ${ }^{38}$

Pembentukan moral justice (moral keadilan) dibutuhkan corps-geest atau spirit of corps (semangat korps). Saat ini telah ada panduan pembangunan semangat korps tersebut yang diatur dalam Peraturan Bersama antara Mahkamah Agung RI dan Komisi Yudisiel RI No. 02/MA/PB/IX/2012 dan Nomor 02/PB/P.-KY/09/2012 tentang Panduan Penegakkan Kode Etik dan Perilaku Hakim. ${ }^{39}$ Pasal 1 butir 14 Peraturan Bersama itu dikatakan bahwa :

"Forum pembelaan diri hakim yang berdasarkan hasil pemeriksaan dinyatakan terbukti melanggar ketentuan sebagaimana diatur dalam peraturan perundang-undangan, serta diusulkan untuk dijatuhi sanksi berat berupa pemberhentian."

Menurut Pasal 11 A ayat (7-13) UU No. 3 Tahun 2009 tentang Perubahan Kedua atas UU No. 14 Tahun 1985 tentang Mahkamah Agung bahwa Majelis Kehormatan Hakim dibentuk bersama oleh Mahkamah Agung dan Komisi Yudisial paling lama 14 hari kerja dihitung sejak usul pemberhentian diterima.

38 Dudu Duswara Machmudin, "Mengembalikan Kewibawaan Mahkamah Agung Sebagai Peradilan Yang Agung" (2013) 10:1 J Konstitusi 33-48 at 44.

39 Ibid at 35. 


\section{KESIMPULAN}

Berangkat dari analisis sebagaimana dilakukan di atas, dapat disimpulkan bahwa legal-realism yang dikonsepkan di Skandinavia dan Amerika sangat cocok digunakan untuk menganalisis hukum di Indonesia, khususnya hukum adat sebagai hukum yang hidup dalam masyarakat. Hukum yang hidup dalam masyarakat dikuatkan melalui putusan hakim maupun melalui aparat penegak hukum sebagai symbol negara. Kemudian, kontribusi legal-realism baik Skandinavian legal-realism maupun American legal-realism sangat besar dan berarti baik dilakukan oleh para antropologi hukum maupun sosiologi hukum. Kontribusi yang diberikan terutama berkenaan dengan pendekatan socio-legal yang saat ini sedang menjadi perhatian di kalangan akademisi. Dengan demikian, peneliti menyarankan agar pengembangan paradigma legal-realism di kalangan akademisi perlu dilakukan. Di sisi lain, penggunaan pendekatan socio-legal sebagai metodelogi dari legal-realism juga perlu diberi tempat dalam kajian hukum di perguruan tinggi.

\section{DAFTAR PUSTAKA}

Cardozo, Benyamin N, Characteristic of Judicial Proccess (New Haven: Yale University Press, 1921).

Gierke, Otto von, The Social Role of Private Law. Diterjemahkan oleh Ewan McGaughey, In King's College London Law School Research Paper. Centre for Business Researh. Cambridge: University of Cambridge; California: California University Press; Berkeley: Berkeley Centre on C (2017).

Golding, Martin P \& William A Edmundson, The Blackwell Guide to the Philosophy of Law and Legal Theory (United States: WileyBlackwell, 2004).

Irianto, Sulistyowati \& Shidarta (eds), Metode Penelitian Hukum: 
Konstelasi \& Refleksi (Jakarta: Yayasan Obor Indonesia, 2011).

Jhering, Rudolf von, Law in Daily Life. Diterjemahkan oleh Henry Goudy (Oxford: Clarendon Press, 1904).

Kartohadiprodjo, Soediman, Pengantar Tata Hukum di Indonesia. Jilid

I: Hukum Perdata (Jakarta: PT. Pembangunan dan Ghalia Indonesia, 1982).

Savigny, Friedrich Carl von, System of the Modern Roman Law.

Diterjemahkan oleh William Holloway (Madras: J. Hingginbotham Publisher, 1867).

Twining, William, Karl Llewellyn and the Realist Movement (Law in context) (London: Weidenfeld \& Nicolson Ltd, 1973).

Adiyanta, FC Susila, "Hukum dan Studi Penelitian Empiris:

Penggunaan Metode Survey sebagai Instrumen Penelitian Hukum Empiris" (2019) 2:4 Adm Law Gov J 697-709.

Alfitri, A, “Ideologi Welfare State Dalam Dasar Negara Indonesia: Analisis Putusan Mahkamah Konstitusi Terkait Sistem Jaminan Sosial Nasional" (2012) 9:3 J Konstitusi 449-472.

Basuki, Udiyo, “Desa Mawa Cara Negara Mawa Tata: Dinamika Pengaturan Desa Dalam Sistem Ketatanegaraan Indonesia" (2017) 5:2 Al-Mazahib 321-344, online: <http:/ejournal.uinsuka.ac.id/syariah/almazahib/article/view/1424>.

Budiono, Arief \& Wafda Vivid Izziyana, “Theistic Legal Realism (Suatu Pilihan Radikal bagi Pengembangan Hukum)" (2018) Huk Transendental Pengemb dan Penegakan Huk di Indones 367-383.

Bybee, Keith J, "Legal Realism, Common Courtesy, and Hypocrisy" (2005) 1:1 Law, Cult Humanit 75-102.

Herawati, Yunie, "Konsep Keadilan Sosial dalam Bingkai Sila Kelima Pancasila" (2014) 18:1 Paradigma 20-27.

Horwitz, Morton J, "The History of the Public/Private Distinction" (1982) 130:6 Univ PA Law Rev 1423-1428. 
Jaya, Nyoman Serikat Putra, "Hukum (Sanksi) Pidana Adat Dalam Pembaharuan Hukum Pidana Nasional” (2016) 45:2 Masal Huk 123-130.

Leiter, Brian, "American Legal Realism" in A Companion to Philos Law Leg Theory (Oxford, UK: Wiley-Blackwell, 2010) 249.

Lismanto, Lismanto \& Yos Johan Utama, "Membumikan Instrumen Hukum Administrasi Negara Sebagai Alat Mewujudkan Kesejahteraan Sosial dalam Perspektif Negara Demokrasi" (2020) 2:3 J Pembang Huk Indones 416-433.

Llewellyn, Karl, "Some Realism about Realism: Responding to Dean Pound" (1931) 44:8 Harv Law Rev 1222-1264.

Machmudin, Dudu Duswara, “Mengembalikan Kewibawaan Mahkamah Agung Sebagai Peradilan Yang Agung" (2013) 10:1 J Konstitusi 33-48.

Masril, Masril \& Ade Kosasih, "Keberlakuan Asas Ne Bis in Idem Terhadap Putusan Pengadilan Adat Dalam Tata Hukum Indonesia" (2019) 4:1 Al Imarah J Pemerintah Dan Polit Islam 49-56.

Mulyadi, Lilik, "EKSISTENSI HUKUM PIDANA ADAT DI INDONESIA: Pengkajian Asas, Norma, Teori, Praktik dan Prosedurnya" (2013) 2:2 J Huk dan Peradil 225-246.

Mustansyir, Rizal, "Landasan Filosofis Mazhab Hukum Progresif: Tinjauan Filsafat Ilmu" (2016) 18:1 J Filsafat 15-25.

Nadir et al, "Philosophical Validity, Theoretical, Normative and Empirical Paradigm of General Principles of Good Governance (Aupb) As a Review of Presidential Impeachment" (2017) 4:1 Brawijaya Law J 95-116.

Pattaro, Enrico, “I Will Tell You about Axel Hägerström: His Ontology and Theory of Judgment" (2010) 23:1 Ratio Juris 123156.

Shidarta, "Membaca Ulang Pemaknaan Keadilan Sosial Dalam Gagasan Revolusi Hukum Soediman Kartohadiprodjo" (2015) 
1:1 Verit Justitia 20-38.

Sumadi, Ahmad Fadlil, "Hukum dan Keadilan Sosial dalam Perspektif Hukum Ketatanegaraan" (2016) 12:4 J Konstitusi 849-871.

Yusuf, Fuad M, “Tindak Pidana Pembunuhan yang Diselesaikan Secara Adat yang Tidak Sesuai dengan Perundang-Undangan (KUHP dan KUHAP) (Studi Kasus Desa Ture dan Desa Lubuk Ruso Kecamatan Pemayung di Kabupaten Batang Hari)" (2009) 9:2 J Ilm Univ Batanghari Jambi 34-46.

Al-Khawarizmi, Damang Averroes, "Relisme Skandinavia”, (2011), online: Negara Huk <https://www.negarahukum.com/relismeskandinavia.html>.

Hakim, Amrie, "Keabsahan Penyelesaian Kasus Pidana Melalui Pengadilan Adat", (2012), online: HukumOnline.com $<$ https://www.hukumonline.com/klinik/detail/ulasan/lt503844 b38e417/351-kuhp-delik-aduan-atau-pidana-murni->.

Prahassacitta, Vidya, "Pandangan Realisme Dari Hukum Jerome Frank", (2018), online: Binus Univ Fac Humanit $<$ https://business-law.binus.ac.id/2018/11/09/pandanganrealisme-hukum-dari-jerome-frank/>.

Tim Yuridisid, "Perselingkuhan Suami-Istri Sanksi Adat Hapuskan Penuntutan Jaksa", (2020), online: Yuridis.id $<$ https://yuridis.id/perselingkuhan-suami-istri-sanksi-adathapuskan-penuntutan-jaksa/>. 